\title{
INTOLERANCE OF PRESERVATIVE-CONTAINING EYE DROPS IN A GLAUCOMA PATIENT: DIAGNOSTIC AND THERAPEUTIC CHALLENGES
}

Frolov MA ${ }^{1}$, Kazakova KA ${ }^{1,2} \bowtie$, Dushina $\mathrm{GN}^{1}$, Frolov $\mathrm{AM}^{1}$, Gonchar PA ${ }^{1}$

${ }^{1}$ Peoples' Friendship University of Russia, Moscow, Russia

${ }^{2}$ Multiprofile Clinic "SM-Clinic", Moscow, Russia

\begin{abstract}
A patient presented to our clinic with stage la open-angle glaucoma of the right eye and stage lla surgically corrected open-angle glaucoma of the left eye. The condition of the ocular surface was interpreted as toxic/allergic conjunctivitis provoked by brimonidine $0.15 \%$. Brimonidine was substituted with non-selective $0.5 \%$; additionally, topical steroids were prescribed. After steroids were discontinued, some of the symptoms came back, including moderate hyperemia and conjunctival edema, which was interpreted as intolerance to a preservative contained in the eye drops. A decision was made to switch from the $\beta$-blocker to its preservative-free formulation; regular IOP monitoring was continued. IOP measured during the next visit was above tolerated, so a preservative-free form of the ocular hypotensive combination drug (an analog of prostaglandin 0.005\% with non-selective $\beta$-blocker $0.5 \%$ ) was introduced to the regimen, with further IOP monitoring. Because the initial diagnosis was wrong, damage to the ocular surface had been aggravated by inadequate therapy. Preservative-free hypotensive eye drops are beneficial for the corneal surface and have a positive effect on a patient's adherence to the regimen.
\end{abstract}

Keywords: glaucoma, preservative, brimonidine, preservative-free form, allergic reactions

Author contribution: Frolov MA — study planning; data analysis and interpretation; Kazakova KA, Dushina GN, Frolov AM, Gonchar PA — study planning; literature analysis; data acquisition, analysis and interpretation; manuscript preparation.

Compliance with ethical standards: the patient gave informed consent to participate in the study and for publication of its results

$\triangle$ Correspondence should be addressed: Kseniya A. Kazakova

Miklouho-Maclay, 6, Moscow, 117198; ponomareva_kseni@mail.ru

Received: 26.12.2019 Accepted: 09.01.2020 Published online: 26.01.2020

DOI: $10.24075 /$ brsmu.2020.005

\section{НЕПЕРЕНОСИМОСТЬ КОНСЕРВАНТОСОДЕРЖАЩИХ ГЛАЗНЫХ КАПЕЛЬ ПРИ ГЛАУКОМЕ: ТРУДНОСТИ ДИАГНОСТИКИ, СЛОЖНОСТИ ЛЕЧЕНИЯ}

М. А. Фролов ${ }^{1}$, К. А. Казакова ${ }^{1,2}$, Г. Н. Душина', А. М. Фролов', П. А. Гончар ${ }^{1}$

1 Российский университет дружбы народов, Москва, Россия

2 Многопрофильный медицинский холдинг «СМ-Клиника», Москва, Россия

\begin{abstract}
В клинику поступил пациент с диагнозом OD o/y глаукома 1а. OS оперированная о/у глаукома Ila. Состояние глазной поверхности расценено как токсико-аллергический конъюнктивит на фоне применения бримонидина 0,15\%. Проведена замена бримонидина 0,15\% на неселективный $\beta$-блокатор 0,5\% и назначены стероиды местно. На фоне отмены стероидов было отмечено частичное возобновление симптомов в виде умеренно выраженных гиперемии и отека конъюнктивы, что было расценено уже как непереносимость консерванта. Было решено заменить $\beta$-блокатор на бесконсервантную форму под регулярным контролем уровня ВГД, дополнительно рекомендованы слезозаменители, не содержащие консервантов. При следующем визите отмечено повышение ВГД выше толерантного, назначена безконсервантная форма комбинированного гипотензивного средства (аналог простагландина 0,005\% с неселективным $\beta$-блокатором 0,5\%) под контролем уровня ВГД. Неправильная постановка диагноза вначале лечения усугубила состояние глазной поверхности. Применение препаратов без консерванта благоприятно влияет на поверхность роговицы и повышает комплаентность пациентов. Ключевые слова: глаукома, консервант, бесконсервантная форма препарата, бримонидин, аллергическая реакция
\end{abstract}

Вклад авторов: М. А. Фролов - планирование исследования, анализ и интерпретация данных; К. А. Казакова, Г. Н. Душина, А. М. Фролов, П. А. Гончар - планирование исследования, анализ литературы, сбор, анализ и интерпретация данных, подготовка черновика рукописи.

Соблюдение этических стандартов: пациент подписал добровольное информированное согласие на участие в исследовании и публикацию данных.

$\bowtie$ Для корреспонденции: Ксения Александровна Казакова

ул. Миклухо-Маклая, д. 6, г. Москва, 117198; ponomareva_kseni@mail.ru

Статья получена: 26.12.2019 Статья принята к печати: 09.01.2020 Опубликована онлайн: 26.01.2020

DOI: $10.24075 /$ vrgmu.2020.005

Topical ocular hypotensive therapy is one of the basic therapeutic methods of reducing intraocular pressure (IOP). Daily instillation of hypotensive eye drops is prescribed to 60$80 \%$ of patients with glaucoma [1]. Such therapy is often longlasting or even life-long, and in some cases a combination of several hypotensive drugs is required.

Today, there is an algorithm for prescribing ocular hypotensive drugs. PGF2 $\alpha$ analogs are often the drugs of first choice since they are the most effective in reducing IOP and have neuroprotective properties. If they fail to work, a switch to prostamides (bimatoprost $0.03 \%$ ) is recommended. If sufficient IOP reduction cannot be achieved with prostamides, carbonic anhydrase inhibitors can be introduced to the regimen. In the absence of a desired outcome, fixed combination therapy should be used as a next-line treatment. Here, one-time instillation of bimatoprost and timolol is the most effective [2].

Summing up, ophthalmologists have a vast armamentarium of different classes of ocular hypotensive medications for treating glaucoma; nevertheless, all of these drugs can have adverse effects associated with their active ingredients or preservatives, which most of eye drops have as a component [3].

Recent years have witnessed extensive research, both in Russia and overseas, into the prevalence of ocular surface pathology in patients with primary glaucoma and the effect of preservatives on the ocular surface [4, 5-9]. There is convincing evidence that preservatives cause the loss of goblet cells, as well as mucin deficiency in the tear film, disrupt the structure of the lipid layer, leading to excessive evaporation and 
hyperosmolarity of the precorneal tear film, produce a cytotoxic effect on conjunctival and corneal epithelial cells, lead to keratinization and inflammatory infiltration in the corneal limbus, provoke elevated cytokines, and maintain inflammatory immune response in the conjunctiva (proinflammatory readiness) $[1,5,7,10]$.

Active ingredients of ocular hypotensive drugs can also have a detrimental effect on the ocular surface. For example, studies have uncovered the mechanisms underlying the development of corneal/conjunctival xerosis in patients receiving instillation of $\beta$-blockers, including suppression of tear secretion and the local anesthetic effect on the ocular surface epithelium; the latter means that production of basal tears is understimulated and conjunctival goblet cells fail to produce enough mucin if the ocular surface epithelium is damaged [5].

Importantly, toxic and allergic reactions to ocular hypotensive drugs can be immediate and delayed, complicating the accurate diagnosis and sometimes resulting in inadequate therapy (antibacterial or antiviral drugs, NSAID, etc.), which, in turn, further aggravates ocular surface damage. A study reports that in patients developing allergy to brimonidine (the $\alpha_{2}$-selective adrenergic receptor agonist), the mean duration of therapy before the onset of allergy was 4 to 15 months [11].

The treatment of patients with intolerance to preservatives contained in hypotensive eye drops is accompanied by a number of difficulties:

- intolerance of ocular hypotensive drugs dictates a switch in the regimen, possibly more than once, meaning that the patient incurs additional costs;

- if eye dryness is provoked by the preservatives in the eye drops, preservative-free artificial tears (lubricating eye drops) should be prescribed instead;

- if IOP control cannot be attained by using a one-drug regimen, the patient should be tested for hypersensitivity to the eye drops planned for use [11];

- if the patient develops toxicity, allergy, corneal/ conjunctival xerosis or it is impossible to exclude hypotensive preservative-containing eye drops from the regimen, adjunct therapy should be prescribed, including systemic and topical antiallergic agents, steroids (which, in turn, can increase IOP) and regenerants. If these drugs contain preservatives, they can provoke allergy just the same;

- in some cases, polyvalent allergy to ocular hypotensive drugs makes medication therapy impossible, so surgery is recommended.

So far, a few preservative-free ocular hypotensive drugs have been approved for use in the Russian Federation. A positive effect of preservative-free hypotensive agents on the ocular surface in comparison with their preservative-containing counterparts has been demonstrated in multiple studies by both Russian and foreign researchers [1, 4, 12-18]. However, their wide use is hindered by a few obstacles:

- only 7 preservative-free hypotensive eye drops have been approved in the Russian Federation;

- the majority of them contain a $\beta$-blocker. The hypotensive effect of $\beta$-blockers is known to attenuate over time, necessitating adding more drugs into the regimen. Besides, the application of nonselective $\beta$-blockers is limited by their systemic side effects.

\section{Clinical case}

The following clinical case seems interesting. Patient K., 67 years, residing in a remote Russian region, presented with complaints of red, burning, watery eyes; the symptoms had set in half a year before the appointment (see Fig.).
Medical history: la open-angle glaucoma of the right eye, lla surgically treated open-angle glaucoma of the left eye. January 2017, the patient underwent nonpenetrating deep sclerectomy and Ahmed valve implantation into the left eye. Postoperatively, the patient received brimonidine instillation in both eyes. No data were available on preoperative IOP in the left eye. In May 2017, the patient presented to a local ophthalmologist, complaining of pronounced redness of both eyes, and was diagnosed with blepharoconjunctivitis. The patient's conjunctival culture was negative for pathogens, but the patient tested positive for Demodex mites and was prescribed anti-Demodex therapy and subconjunctival injections of gentamicin and dexamethasone, reporting improvement shortly thereafter. However, in the months that followed, the patient had a few episodes of hyperemia. His condition started to deteriorate in early November, 2017. The patient sought medical advice at different clinics in the region of his residence and also outside it. Repeated culture tests were negative; a few mature Demodex mites were detected. A conjunctival smear test revealed elevated white blood cells. The patient was prescribed topical antiseptics, antibiotics, interferon and its inducer, antihistamines, corticosteroids, lubricants for corneal protection, and eye hygiene, with no positive effect.

The patient contacted our clinic in December 2017. On examination: best corrected visual acuity (BCVA) 0.9 OD, 0.8 OS. IOP measured by air-puff tonometry: 18-19 mmHg OD, 20-21 mmHg OS. Eyelids were red and swollen; tear producing organs were intact; excess tear production was observed. The conjunctiva appeared pronouncedly red, with swollen fornices, conjunctival follicles and eyelids; eye discharge was flaky and scanty. Old subepithelial opacities were detected on the retina in both eyes. On palpation, IOP was normal. The condition of the ocular surface was interpreted as toxic/allergic conjunctivitis provoked by brimonidine $0.15 \%$.

\section{Clinical case discussion}

Substituting brimonidine $0.15 \%$ with nonselective $\beta$-blocker $(0.5 \%)$ and adding temporary topical steroids to the regimen, with regular IOP monitoring, led to improvement, both subjective and objective. After steroids were discontinued, some of the symptoms came back, including moderate hyperemia and conjunctival edema, which was interpreted as intolerance to a preservative contained in the eye drops. A decision was made to switch from the $\beta$-blocker to its preservative-free form; regular

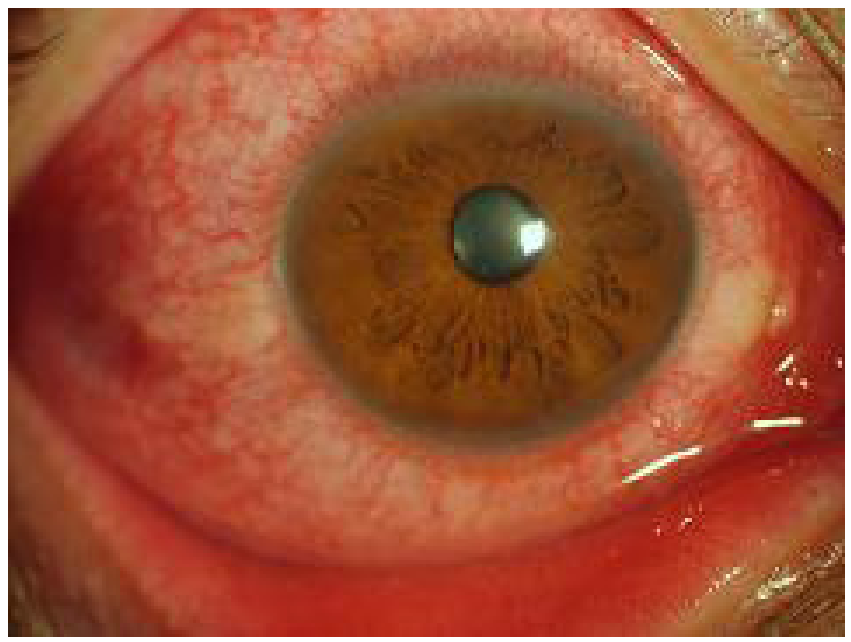

Fig. The patient's right eye. Conjunctival and pericorneal hyperemia. Conjunctival follicles and moderate edema of the lower eyelid 
IOP monitoring was continued. Additionally, preservative-free artificial tears were recommended. The choice of the marketed form was dictated by the absence of other preservative-free ocular hypotensive drugs in the patient's area of residence.

The patient did not show up for the scheduled checkup examination; we did not hear from him for over 9 months. As he told us later, IOP measurements had been taken at a healthcare facility in the patient's area of residence. The patient contacted us again in October 2018, complaining of deteriorating vision in the left eye. According to the patient and Maklakov tonometer readings in the medical history, IOP in the operated eye had been fluctuating between 15 and $23 \mathrm{mmHg}$. On examination: Vis OS $=0.2, \mathrm{BCVA}=0.5$. The eyelids looked healthy, the eyes were not watery, the conjunctiva also looked normal. Ophthalmoscopy results: pallor of the optic disc, excavation at the margin. Automated static perimetry revealed constriction of the visual field $\left(30^{\circ}\right)$ at the nasal side and multiple absolute central scotomas. IOP: $15 \mathrm{mmHg}$ OD, $24 \mathrm{mmHg}$ OS.

Due to the deteriorating visual acuity and elevated (24 $\mathrm{mmHg}$ IOP in the left eye, the patient was advised to repeat glaucoma surgery at his local healthcare facility. Medication therapy was also prescribed, including a preservative-free formulation of the ocular hypotensive combination drug (an analog of prostaglandin $0.005 \%$ with non-selective $\beta$-blocker $0.5 \%)$. Further IOP monitoring was recommended. Because the prescribed medication was not available in the patient's area of residence, he had to order it from another town.
The recommended glaucoma surgery was not performed. The patient presented to our clinic again in January 2019. The visual field defect was not progressing; the condition of the optic disc was stable. IOP: $16 \mathrm{mmHg}$ OD, $19 \mathrm{mmHg}$ OS. The patients complained of occasional hyperemia, accompanying the intake of artificial tears, which could have been an adverse reaction to the instillation of the prescribed prostaglandin analog. IOP measured at the patient's local healthcare facility was not stable, increasing to $22-24 \mathrm{mmHg}$ in the left eye.

We strongly advised the patient to undergo repeat glaucoma surgery because he had intolerance to preservativecontaining ocular hypotensive drugs, the drugs did not ensure a stable hypotensive effect, and he lived in a remote region, which complicated proper treatment monitoring.

\section{CONCLUSIONS}

Misinterpretation of the etiology of conjunctivitis/ blepharoconjunctivitis results in polypragmasy. Adding more drugs to the regimen may aggravate damage to the ocular surface and entails costs. In the absence of preservativefree ocular hypotensive eye drops, preservative-containing formulations used for treating glaucoma can trigger its progression. Insufficient reduction of intraocular pressure does not allow a patient to discontinue preservative-containing drugs, which negatively affects the quality of a patient's life and their adherence to the regimen and can lead to repeat surgery.

\section{References}

1. Astahov SYu, Tkachenko NV. Taflotan - pervyj analog prostaglandina-F2 $\alpha$ bez konservantov: preimushchestva $v$ lechenil bol'nyh pervichnoj otkrytougol'noj glaukomoj. Oftal'mologicheskie vedomosti. 2016; 9 (2): 59-68.

2. Egorov AE, Glazko NG, Movsisyan AB. Gipotenzivnaya nejroprotektivnaya terapiya glaukomy: realii i perspektivy. Russkij medicinskij zhurnal. Klinicheskaya oftal'mologiya. 2019; 19 (3): 128-36.

3. Yani EV, Seliverstova KE. Toksiko-allergicheskij kon"yunktivit u pacientov s pervichnoj glaukomoj na fone medikamentoznogo gipotenzivnogo lecheniya. Farmateka. 2016; 20 (333): 12-14.

4. Erichev VP, Ambarcumyan KG, Fedorov A.A. Klinikomorfologicheskie dokazatel'stva vliyaniya konservantov na poverhnost' glaza pri pervichnoj otkrytougol'noj glaukome. Nacional'nyj zhurnal glaukoma. 2014; 13 (4): 13-22.

5. Brzheskij W, Radhuan M. Glaukoma i sindrom "suhogo glaza". Oftal'mologicheskie vedomosti. 2014; 7 (2): 37-49.

6. Safonova TN, Fedorov AA, Zabegajlo AO, Egorova GB, Mitichkina TS Lechenie sindroma "suhogo glaza" pri pervichnoj glaukome. Nacional'nyj zhurnal glaukoma. 2015; 14 (4): 36-43.

7. Erichev VP, Ambarcumyan KG. Osobennosti gipotenzivnoj terapii bol'nyh glaukomoj preparatami, ne soderzhashchimi konservantov. Prakticheskaya medicina. 2012; 4 (59): 194-6.

8. Erb C, Gast U, Schremmer D. German register for glaucoma patients with dry eye. I. Basic outcome with respect to dry eye. Graefe's Arch Clin Exp Ophthalmol. 2008; 246 (11): 1593-601.

9. Leung EW, Medeiros FA, Weinreb RN. Prevalence of ocular surface disease in glaucoma patients. J Glaucoma. 2008; 17 (5): 350-5.

10. Astahov Syu, Graboveckij VR, Nefedova DM, Tkachenko NV. Preimushchestva i nedostatki gipotenzivnyh kapel' bez

konservanta. Oftal'mologicheskie vedomosti. 2011; 4 (20): 95-97.

11. Shtejner I, Branchevskij S. Problemy differencial'noj diagnostiki otsrochennoj allergicheskoj reakcii u pacientov, poluchajushhih mestnoe gipotenzivnoe lechenie glaukomy. Vrach. 2016; (12): 62-4.

12. Alekseev IB, Koroleva IA. Beskonservantnye gipotenzivnye preparaty: preimushhestva terapii. Russkij medicinskij zhurnal. Klinicheskaja oftal'mologija. 2019; 19 (3): 137-42.

13. Antonov AA, Kozlova IV, Mitichkina TS, Vedmedenko II. Beskonservantnaya terapiya glaukomy u pacientov, perenesshih keratorefrakcionnye operacii. Russkij medicinskij zhurnal. Klinicheskaya oftal'mologiya. 2019; 19 (3): 165-70.

14. Loskutov IA, Korneeva AV. Beskonservantnaya forma fiksirovannoj kombinacii bimatoprosta i timolola $v$ povyshenii komplaensa $\mathrm{i}$ effektivnosti lecheniya pacientov s pervichnoj otkrytougol'noj glaukomoj. Rossijskij oftal'mologicheskij zhurnal. 2018: 11 (2): 95-101.

15. Onishchenko AL, Dimaksyan MV, Kolbasko AV, ZHilina NM. Lechenie pervichnoj otkrytougol'noj glaukomy $\beta$-ksololom bez konservanta: ocenka gipotenzivnogo effekta i glaznoj poverhnosti. Vestnik oftal'mologii. 2015; 131 (20): 76-80.

16. Egorov EA. Novye formy selektivnyh $\beta$-blokatorov $\vee$ lechenii glaukomy. Klinicheskaya oftal'mologiya. 2014; 14 (3): 131-5.

17. Bourne R, Kaarniranta K, Lorenz K, Traverso CE, Vuorinen J, Ropo A. Changes in ocular signs and symptoms in patients switching from bimatoprost-timolol to tafluprost-timolol eye drops: an open-label phase IV study. BMJ Open. 2019; 9 (4).

18. Pillunat LE, Eschstruth P, Häsemeyer S, Thelen U, Foja C, Leaback $R$, et al. Preservative-free bimatoprost $0.03 \%$ in patients with primary open-angle glaucoma or ocular hypertension in clinical practice. Clin Ophthalmol. 2016; 12 (10): 1759-65. 


\section{Литература}

1. Астахов С. Ю., Ткаченко Н. В. Тасрлотан - первый аналог простагландина-F2 $\alpha$ без консервантов: преимущества в лечении больных первичной открытоугольной глаукомой. Офтальмологические ведомости. 2016; 9 (2): 59-68.

2. Егоров А. Е., Глазко Н. Г., Мовсисян А. Б. Гипотензивная и нейропротективная терапия глаукомы: реалии и перспективы. Русский медицинский журнал. Клиническая офтальмология. 2019; 19 (3): 128-36.

3. Яни Е. В., Селиверстова К. Е. Токсико-аллергический конъюнктивит у пациентов с первичной глаукомой на фоне медикаментозного гипотензивного лечения. Фарматека. 2016; 20 (333): 12-14.

4. Еричев В. П., Амбарцумян К. Г., Федоров А. А. Клиникоморфологические доказательства влияния консервантов на поверхность глаза при первичной открытоугольной глаукоме. Национальный журнал глаукома. 2014; 13 (4): 13-22.

5. Бржеский В. В., Радхуан М. Глаукома и синдром «сухого глаза». Офртальмологические ведомости. 2014; 7 (2): 37-49.

6. Сафонова Т. Н., Федоров А. А., Забегайло А. О., Егорова Г. Б., Митичкина Т. С. Лечение синдрома «сухого глаза» при первичной глаукоме. Национальный журнал глаукома. 2015 14 (4): 36-43.

7. Еричев В. П., Амбарцумян К. Г. Особенности гипотензивной терапии больных глаукомой препаратами, не содержащими консервантов. Практическая медицина. 2012; 4 (59): 194-6.

8. Erb C, Gast U, Schremmer D. German register for glaucoma patients with dry eye. I. Basic outcome with respect to dry eye. Graefe's Arch Clin Exp Ophthalmol. 2008; 246 (11): 1593-601.

9. Leung EW, Medeiros FA, Weinreb RN. Prevalence of ocular surface disease in glaucoma patients. J Glaucoma. 2008; 17 (5): 350-5.

10. Астахов С. Ю. Грабовецкий В. Р., Неседова Д. М., Ткаченко Н. В. Преимущества и недостатки гипотензивных капель без консерванта. Офртальмологические ведомости. 2011; 4 (20): 95-7.
11. Штейнер И., Бранчевский С. Проблемы дифференциальной диагностики отсроченной аллергической реакции у пациентов, получающих местное гипотензивное лечение глаукомы. Врач. 2016; (12): 62-4.

12. Алексеев И. Б., Королева И. А. Бесконсервантные гипотензивные препараты: преимущества терапии. Русский медицинский журнал. Клиническая офттальмология. 2019; 19 (3): 137-42.

13. Антонов А. А., Козлова И. В., Митичкина Т. С., Ведмеденко И. И. Бесконсервантная терапия глаукомы у пациентов, перенесших кераторефракционные операции. Русский медицинский журнал. Клиническая офтальмология. 2019; 19 (3): 165-70.

14. Лоскутов И. А., Корнеева А. В. Бесконсервантная форма фиксированной комбинации биматопроста и тимолола в повышении комплаенса и эффективности лечения пациентов с первичной открытоугольной глаукомой Российский офртальмологический журнал. 2018; 11 (2): 95-101.

15. Онищенко А. Л., Димаксян М. В., Колбаско А. В., Жилина Н. М. Лечение первичной открытоугольной глаукомы $\beta$-ксололом без консерванта: оценка гипотензивного эффекта и глазной поверхности. Вестник офтальмологии. 2015; 131 (20): 76-80.

16. Егоров Е. А. Новые формы селективных $\beta$-блокаторов в лечении глаукомы. Клиническая офтальмология. 2014; 14 (3): $131-5$.

17. Bourne R, Kaarniranta K, Lorenz K, Traverso CE, Vuorinen J, Ropo A. Changes in ocular signs and symptoms in patients switching from bimatoprost-timolol to tafluprost-timolol eye drops: an open-label phase IV study. BMJ Open. 2019; 9 (4).

18. Pillunat LE, Eschstruth P, Häsemeyer S, Thelen U, Foja C Leaback $R$, et al. Preservative-free bimatoprost $0.03 \%$ in patients with primary open-angle glaucoma or ocular hypertension in clinical practice. Clin Ophthalmol. 2016; 12 (10): 1759-65. 